\title{
Seasonal and regional features of long-term precipitation changes in Japan
}

\author{
by \\ Satoshi Oguchi ${ }^{1}$ and Fumiaki Fujibe ${ }^{2}$ \\ ${ }^{1}$ Graduate School of Life and Environmental Sciences, University of Tsukuba \\ (Present affiliation: International Meteorological \& Oceanographic Consultants Co., Ltd.) \\ ${ }^{2}$ Forecast Research Department, Meteorological Research Institute, Japan Meteorological Agency
}

(Received June 21, 2011; Accepted December 16, 2011; Published March 2, 2012)

\begin{abstract}
We documented precipitation changes in Japan from 1901 to 2009 using five climatological indices and daily data at 51 stations. Annual precipitation amount (PRCPTOT) decreased over the 109 years, and the number of days with precipitation (R1mm) decreased even more, causing their ratio (SDII), an indicator of precipitation intensity, to increase. The consecutive dry days index (CDD) increased, and the consecutive wet days index (CWD) decreased, as a result of fewer days of precipitation. Linear trends of the indices during each season show complicated regional features that are highly incoherent among the seasons, whereas trends of monthly and six-pentad (thirty-day) mean values show subseasonal variations, which implies heterogeneous climate changes on the sub-seasonal scale. Some of these results, such as the tendency for the Baiu period to shift to later in the summer over eastern and western Japan, agree with climate change projections, although more robust information on the regionality and seasonality of long-term precipitation trends will require further study on underlying changes in atmospheric circulation systems.
\end{abstract}

\section{Introduction}

Long-term precipitation variations have received much attention from disaster mitigation and water resource managers. In many regions of the world, the frequency of heavy precipitation events, or the proportion of total rainfall from such heavy events, has increased during the last several decades, consistent with increases in atmospheric water vapor (IPCC, 2007; Emori and Brown, 2005). In studies of precipitation trends in Japan, heavy precipitation events (100 $\mathrm{mm}$ /day or more) have become more frequent during the last century, although days with precipitation are less frequent (Fujibe et al., 2006). The increase in heavy precipitation appears to be more pronounced in western Japan than elsewhere, and more so in autumn than in other seasons (Fujibe et al., 2006), but detailed analysis of regional and seasonal features is hindered by the scarcity of heavy precipitation events.

A number of researchers have explored seasonal and sub-seasonal features of long-term precipitation change,

Corresponding author: Fumiaki Fujibe

Meteorological Research Institute,

1-1 Nagamine, Tsukuba, Ibaraki 305-0052, Japan.

E-mail: ffujibe@mri-jma.go.jp especially for summer. Endo (2011) saw that precipitation had decreased in the early Baiu season (early to mid-June) over many years, but had increased in the late Baiu season (mid- to late July) over most of eastern and western Japan, in rough agreement with changes projected by climate models (Kusunoki and Mizuta, 2008; Kusunoki et al., 2011). In view of the distinct seasonal changes and the complex topography of Japan, we chose to do a detailed analysis of precipitation changes throughout the year and over the whole country.

Recently Alexander et al. (2006) and WMO (2009) developed a number of standardized indices better suited for climatological surveys of precipitation; they facilitate seamless combination of analyses done in different countries. We intend to document the climatology of precipitation changes in Japan using these indices, on data from over a hundred years, with attention to their seasonal and regional details.

\section{Data and analysis}

For our analysis, we used quality-checked daily precipitation data from 51 stations (Fig. 1) of the Japan Meteorological Agency (JMA) collected from 1901 to 2009. From the standard indices, we selected five (Table 1) that were statistically robust and suitable for detailed regional and seasonal 


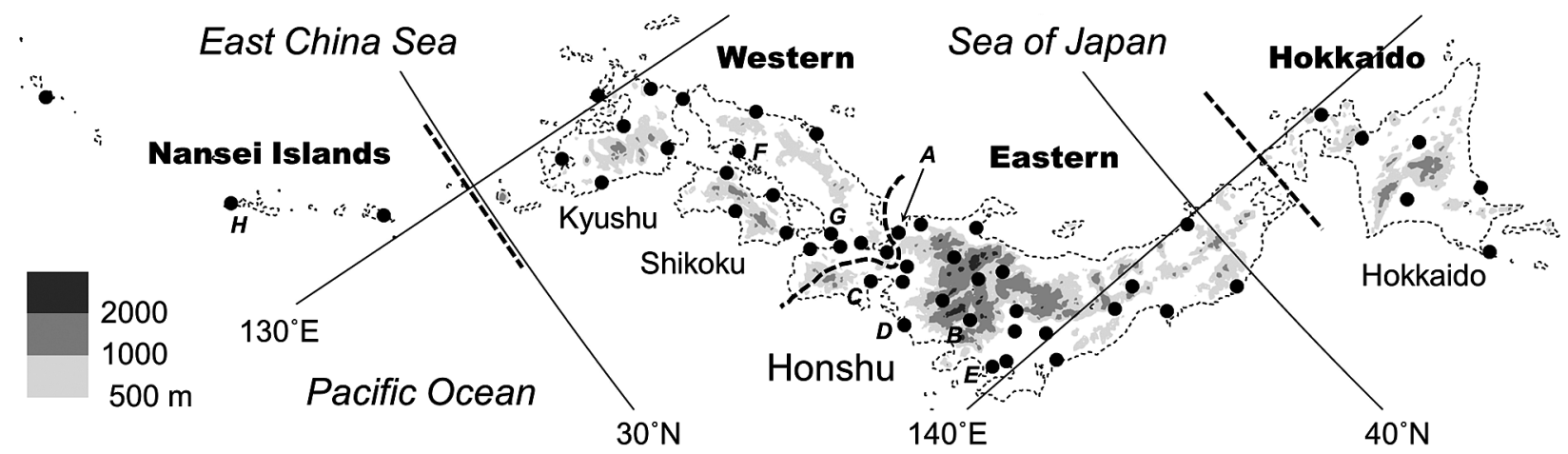

Fig. 1 Stations used for analysis. Letters A-H mark the stations listed in Table 1.

Table 1. List of stations having more than three missing records in a month.

\begin{tabular}{ll}
\hline \multicolumn{1}{c}{ Index } & \multicolumn{1}{c}{ Definition } \\
\hline PRCPTOT & Total precipitation \\
R1mm & Count of days on which precipitation $\geq 1 \mathrm{~mm}$ \\
SDII & Simple daily intensity index: PRCPTOT/R1mm \\
CDD & Consecutive dry days: Maximum length of days on \\
& which precipitation $<1 \mathrm{~mm}$ \\
CWD & Consecutive wet days: Maximum length of days on \\
& which precipitation $\geq 1 \mathrm{~mm}$ \\
\hline
\end{tabular}

analyses. We defined the occurrence date of consecutive dry days (CDD) or consecutive wet days (CWD) as the middle day of a set of consecutive dry or wet days in a period.

If data from a station were missing for more than three days in a month, then the data of that month and station were not used (Table 2). Otherwise, we regarded missing data as 0 $\mathrm{mm}$ when we calculated total precipitation (PRCPTOT) and the number of days with precipitation $\geq 1 \mathrm{~mm}$ (R1mm); missing data were ignored when we calculated CDD and CWD.

Data were recorded with a precision of $0.1 \mathrm{~mm}$ until the mid-1960s (until 1967, at most stations), when the precision changed to $0.5 \mathrm{~mm}$ as automated tipping bucket rain

Table 2. Indices used for analysis.

\begin{tabular}{lllc}
\hline \multicolumn{1}{c}{ Station } & \multicolumn{1}{c}{ Periods of missing data } & $\begin{array}{c}\text { Number } \\
\text { of months }\end{array}$ \\
\hline A & Fukui & $\begin{array}{l}\text { Feb.-Dec. 1938 (except May, July } \\
\text { and Oct.); June 1941; July-Aug. }\end{array}$ & 11 \\
& & 1945 & \\
B & Kofu & June-July 1945 & 2 \\
C & Tsu & July 1989 & 1 \\
D & Hamamatsu & June 1945 & 1 \\
E & Yokohama & Aug.-Dec.1923 & 5 \\
F & Kure & Apr. 1945; June 1945-Sep. 1946 & 17 \\
G & Kobe & Mar. 1945 & 1 \\
H & Naha & Jan.-July 1923; May 1924; Oct. & 83 \\
& & 1943; Sep. 1944; Feb. 1945-Dec. & \\
\hline & & 1950; Feb.-Mar. 1951 & \\
\hline
\end{tabular}

gauges were deployed. To avoid the inhomogeneity due to the change, we transformed data with $0.1 \mathrm{~mm}$ precision to $0.5 \mathrm{~mm}$ precision using the method of Kanae et al. (2004) and Fujibe et al. (2006). Fujibe et al. (2006) also evaluated the effect of evaporation loss from the tipping bucket by assuming an extreme case in which rain water remaining in the bucket was totally lost at the date change. They found that the bias due to evaporation loss was not large enough to alter the analysis results, although the trend of precipitation days had changed slightly (from $-0.15 \% /$ year to $-0.09 \%$ /year for 1901 to 2004). We confirmed this finding in the present study. In this article, we present results without regard for any evaporation loss.

The linear trend of each index, except SDII (defined below), was calculated from the least-squares condition

$$
\sum_{n}\left[P_{n}-\left\{a+b\left(n-\frac{n_{1}+n_{2}}{2}\right)\right\}\right]^{2} \rightarrow \text { minimum, }
$$

where $n$ is year, $P_{n}$ is the value of the index in the year $n, n_{1}=$ 1901 , and $n_{2}=2009$. In the analysis for a specified season or month, $P_{n}$ stands for the value at that time of the year, in year $n$. The least-squares coefficient $a$ gives the mean, and $b$ gives the trend of $P_{n}$. We define another index SDII (simple daily intensity index) as the intensity of daily precipitation, or SDII $=$ PRPCTOT $/ \mathrm{R} 1 \mathrm{~mm}$. For SDII, we used the condition

$$
\sum_{n} R_{n}\left[S_{n}-\left\{a+b\left(n-\frac{n_{1}+n_{2}}{2}\right)\right\}\right]^{2} \rightarrow \text { minimum }
$$

where $R_{n}=\mathrm{R} 1 \mathrm{~mm}$ and $S_{n}=\mathrm{SDII}$ in year $n$, instead of condition (1), because $S_{n}$ becomes singular if $R_{n}$ is very small, which can occur when data for a limited time of the year from a limited number of stations are analyzed.

\section{Results}

\subsection{Annual statistics}

In the time series of each index averaged over all stations (Fig. 2), the precipitation amount (PRCPTOT) decreased 

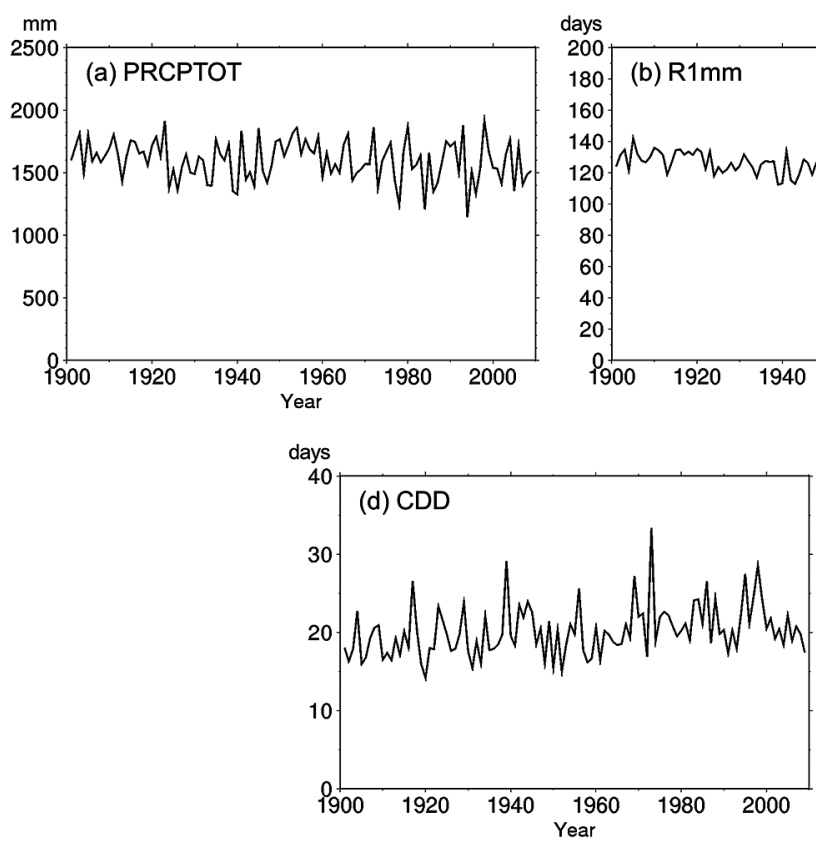

$\mathrm{mm} /$ day
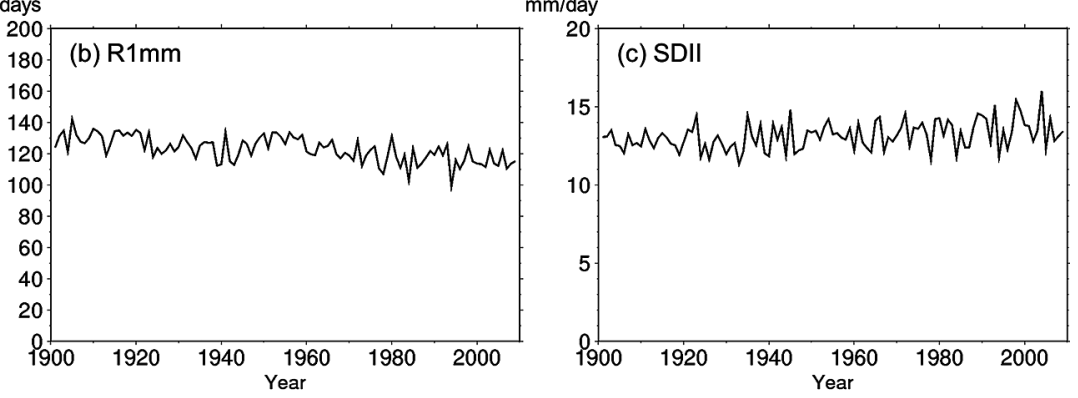

Fig. 2 Time series of annual values of each index averaged over all stations.

over the 109 year period by $-0.055 \% /$ year, and the number of days with precipitation, $\mathrm{R} 1 \mathrm{~mm}$, decreased faster, at a rate of $-0.126 \% /$ year. Accordingly, their ratio, precipitation intensity or SDII, increased slightly at $+0.076 \%$ /year. Consecutive dry days (CDD) trended upward at $+0.159 \% /$ year, and consecutive wet days (CWD) downward at $-0.151 \%$ year, respectively. These trends were statistically significant at the $5 \%$ level.

The decline in total precipitation (PRCPTOT) was most conspicuous in central Honshu (Fig. 3), whereas the decline of R1mm was evident at most stations except for a few in Hokkaido. SDII increased at many stations, although at stations in central Honshu where PRCPTOT decreased remarkably, the change was slight. Finally, CDD increased and CWD decreased at most stations, with statistical significance at some of them.

\subsection{Seasonal statistics}

Statistically significant changes in the spring (March to May) were relatively sparse (Fig. 4), except for downward trends of R1mm in western Japan and northern Honshu. CDD increased in spring at some stations in northern Japan and on the Nansei Islands, and CWD decreased at some stations in Japan.

In summer (June to August; Fig. 5), PRCPTOT decreased at many locations on the Pacific Ocean side of western Japan, and R1mm decreased in Hokkaido and on the Nansei Islands. We observed the opposite trend on the Sea of Japan coast in central and western Japan, where PRCPTOT and SDII increased. Summer trends in CDD and CWD were mostly not significant, although CWD decreased at some stations in central Honshu and western Japan.
In autumn (September to November; Fig. 6), PRCPTOT, R1mm, and CWD all declined significantly, and CDD increased at many locations in eastern and western Japan, as well as on the Nansei Islands. Trends in SDII were weakly positive but mostly not significant.

In winter (December to February; Fig. 7), R1mm declined in eastern Japan, and on the Sea of Japan coast of western Japan and the Nansei Islands. PRCPTOT decreased at some stations on the Sea of Japan side of Honshu. Also, CDD increased and CWD decreased at many stations in eastern and western Japan, especially on the Sea of Japan side, and in the Nansei Islands.

From the viewpoint of seasonal coherency, regional features of the trends were highly dissimilar among the seasons. For PRCPTOT, the spatial pattern of annual trends (Fig. 3), especially the large decrease in central Honshu, was not found in any season, so that regional features of each season were largely canceled out in the annual statistics. In fact, we found considerable month-to-month variability in the monthly statistics. Among the four months from November to February (Fig. 8), we observed significant decreases in PRCPTOT at many stations in December, but insignificant trends at most stations in November, January, and February. Similar month-to-month variations were found for other seasons and indices (not shown). In the next subsection, we present six-pentad (thirty-day) running sums of PRCPTOT and $\mathrm{R} 1 \mathrm{~mm}$ for four regions of the country, in order to survey the sub-seasonal variability in precipitation trends.

\subsection{Sub-seasonal features}

The annual cycle of precipitation trend (PRCPTOT) (in six-pentad running sums) for the four regions of Japan 

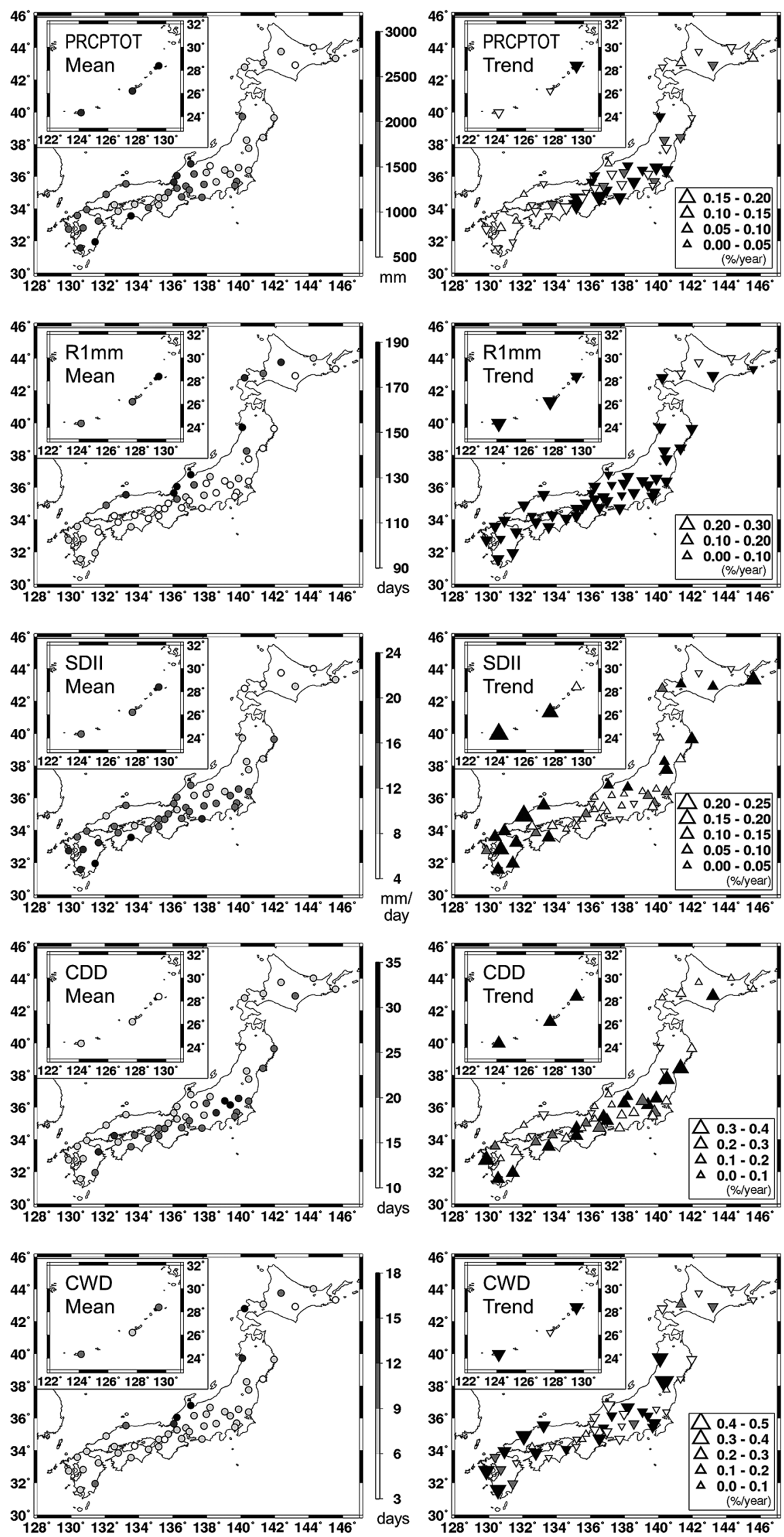

Fig. 3 Long-term mean and trend of the annual values of each index at each station. For the long-term mean (left panels), the shading inside a circle indicates the index value as shown in the legend. For the trend (right panels), the size of a triangle indicates magnitude of the trend, and its orientation indicates the sign (upright for positive and inverted for negative). Black and gray tones indicate statistical significance at the $5 \%$ and $10 \%$ levels, respectively. 

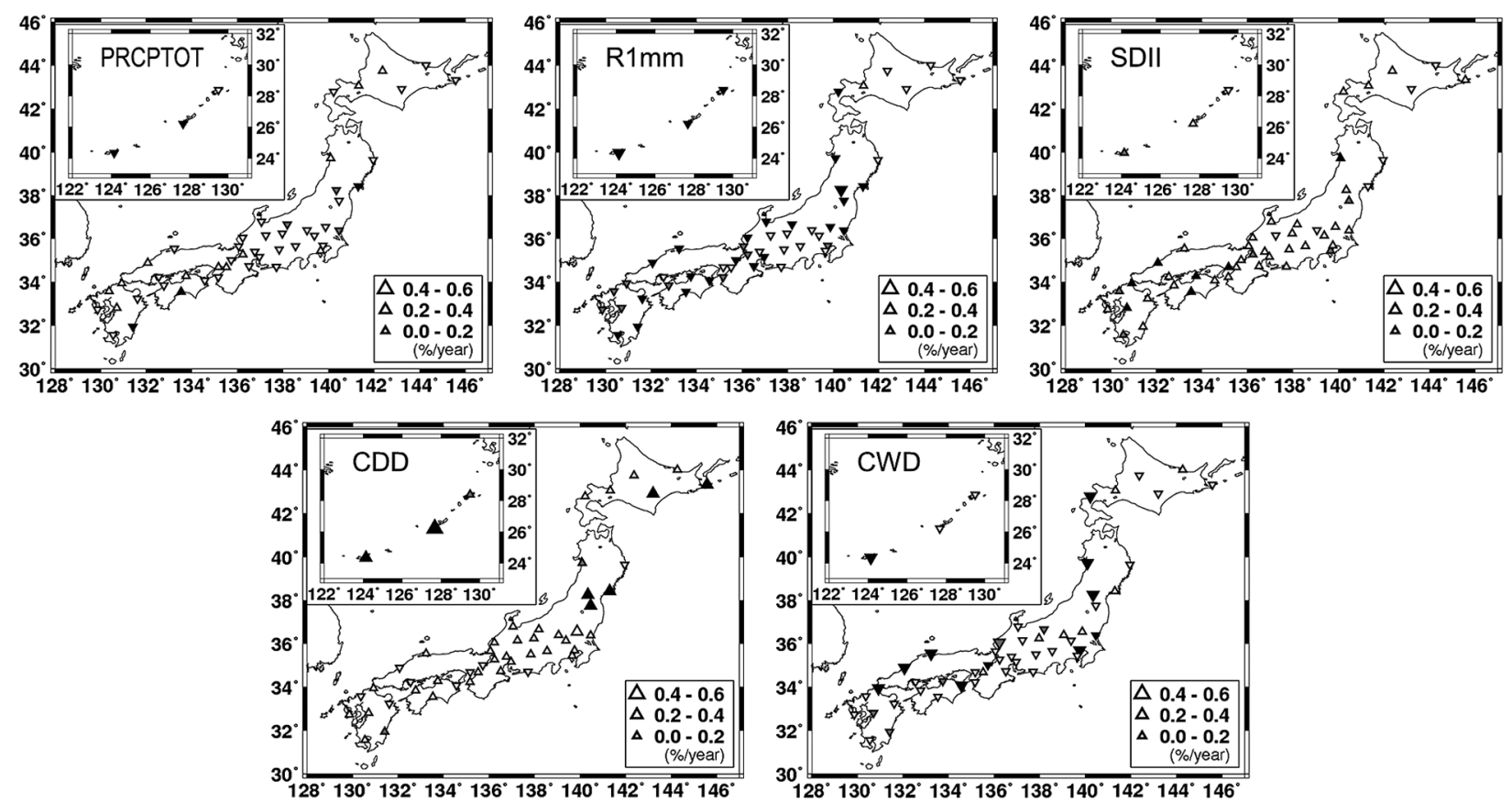

Fig. 4 Trend of each index in spring (March to May). In Figs. 4 to 8, the size, orientation, and shading of each triangle have the same meaning as in the right panels of Fig. 3.
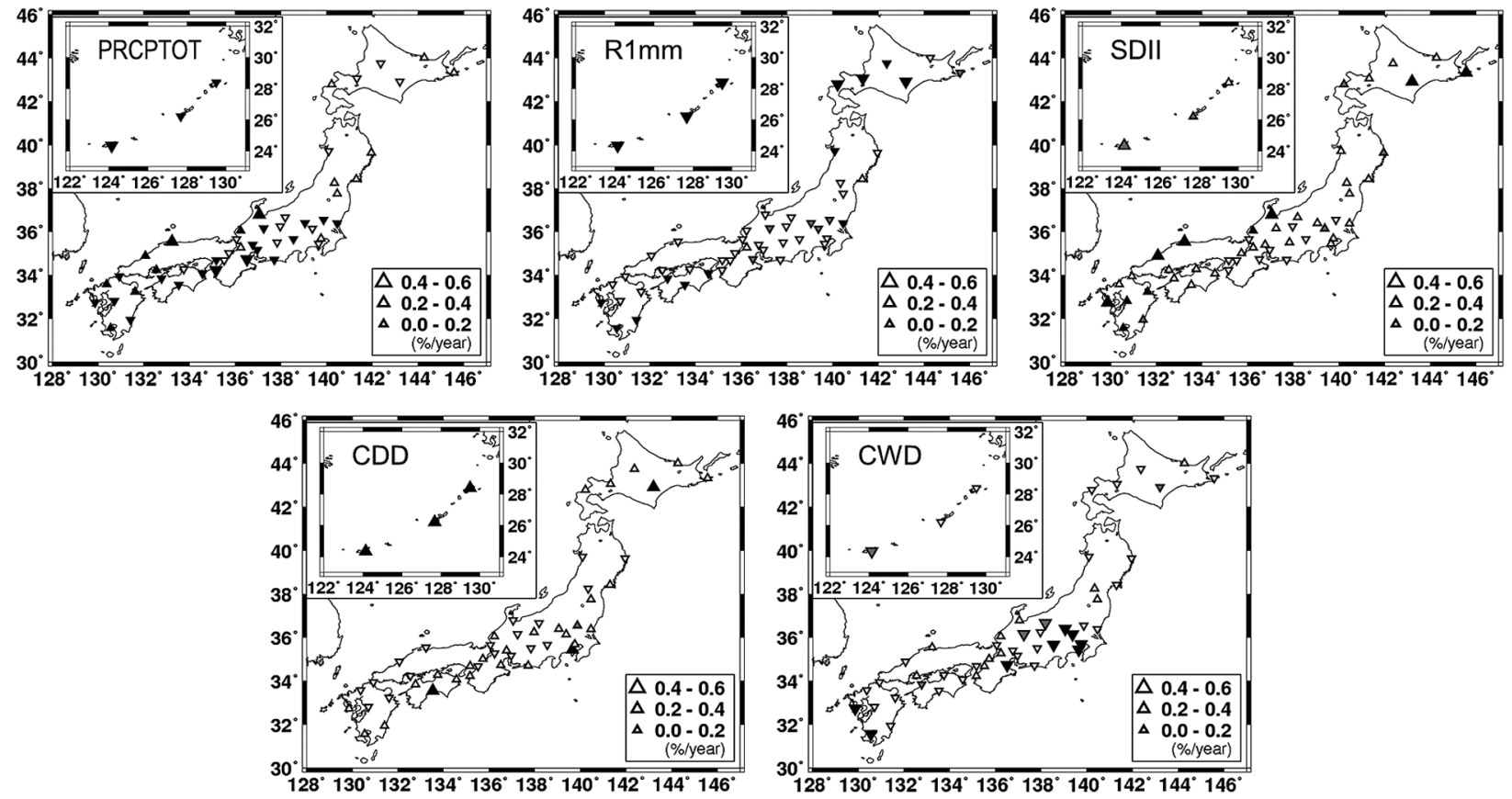

Fig. 5 Trend of each index in summer (June to August).

shown in Fig. 1 appears to exhibit seasonal variations on the scale of one to two months (Fig. 9a). We first used 11 regions in our analysis, but then for simplicity merged nine of them (excepting Hokkaido and the Nansei Islands) into either eastern or western Japan, because they showed several common patterns. In the Nansei Islands, precipitation decreased remarkably from late June into early July (about $-0.4 \%$ year) and increased from late August into early September (about $+0.3 \% /$ year). In eastern and western Japan, precipitation decreased in June and September, and increased from July to August, so that the midsummer dry season tended to become indistinct (although the statistical significance of this result is limited). The number of days with precipitation ( $\mathrm{R} 1 \mathrm{~mm})$ diminished throughout the year in all regions, except in 

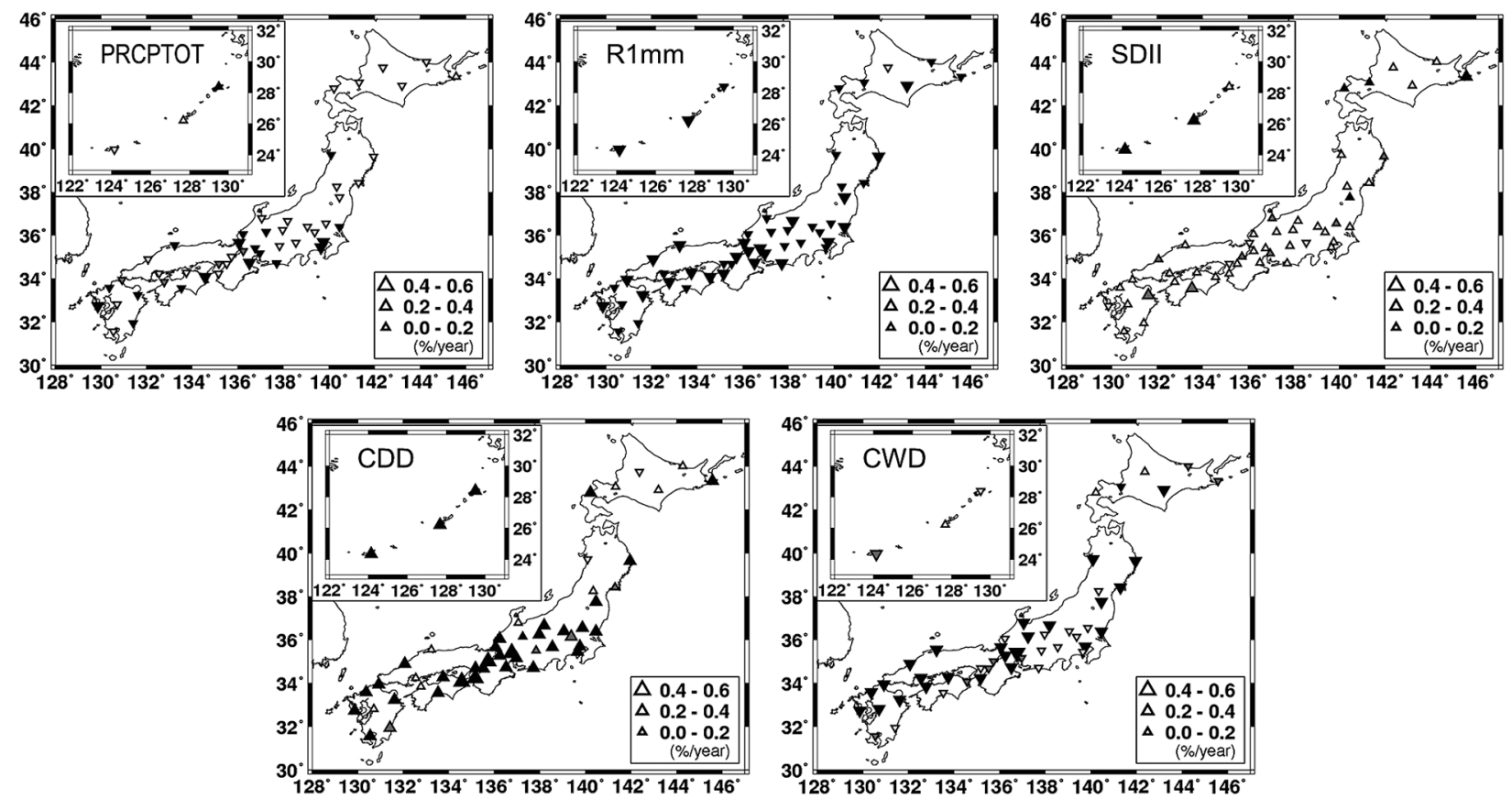

Fig. 6 Trend of each index in autumn (September to November).
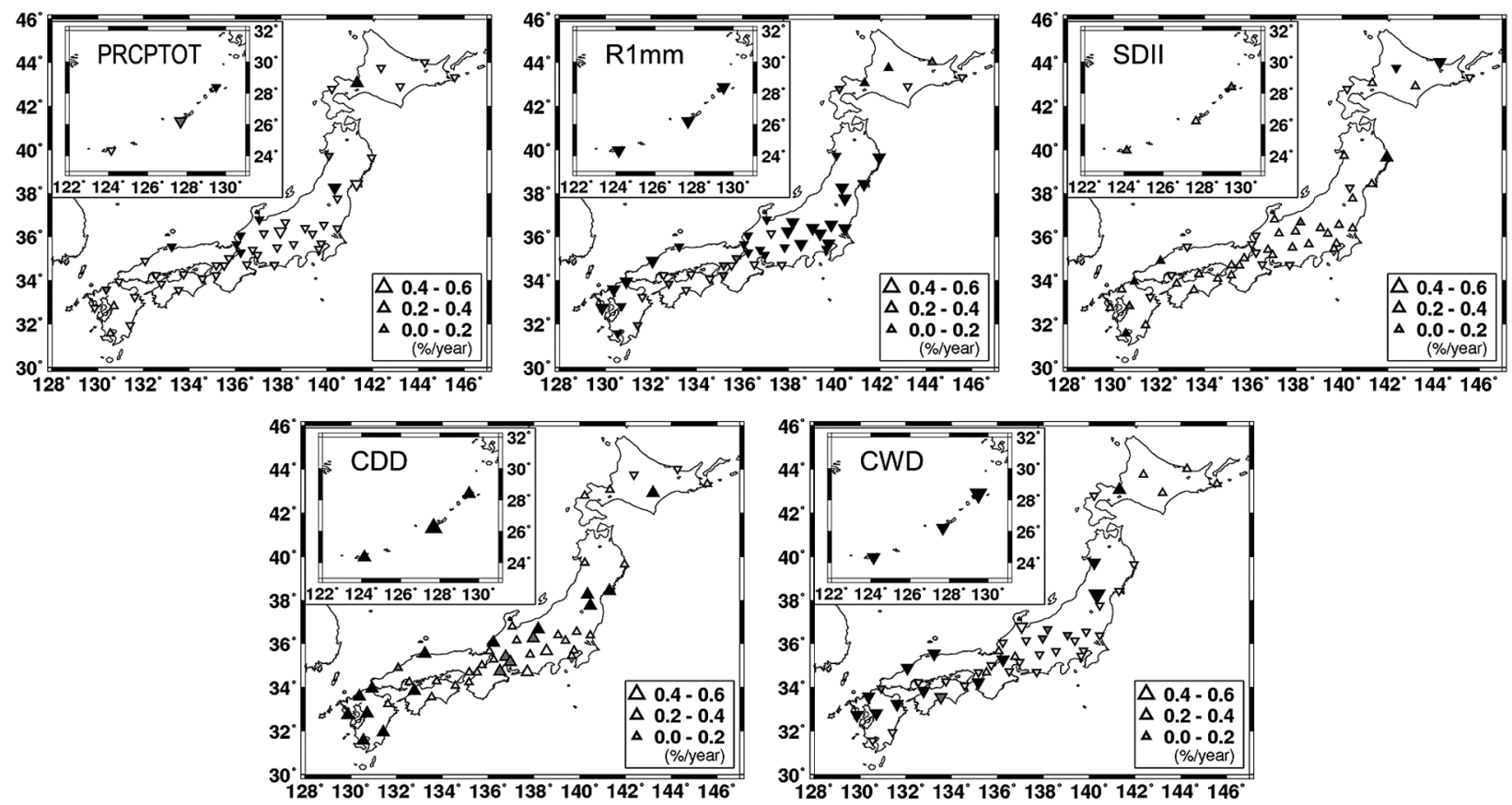

Fig. 7 Trend of each index in winter (December to February)

Hokkaido, where R1mm increased in midwinter (Fig. 9b). The Nansei Islands in particular showed a remarkable decrease (about $-0.3 \% /$ year) in midwinter and from late June to early July ( $-0.5 \% /$ year). We also found some features that correspond to those described here in our seasonal analyses (Figs. 4-7), although the seasonal analyses show more detailed regional features at the cost of sub-seasonal resolution. Trends of precipitation intensity SDII (Fig. 9c) were positive for most of the year. Larger increases were found in midsummer in Hokkaido, in late autumn in western Japan, and in early autumn on the Nansei Islands.

In order to observe how these changes are reflected in the seasonal march of precipitation, we plotted annual cycles of precipitation and of $\mathrm{R} 1 \mathrm{~mm}$ for four sub-periods in the 109-year analysis period, each 27 years long (except 28 years for the last one) in Fig. 10. Features of the annual patterns 

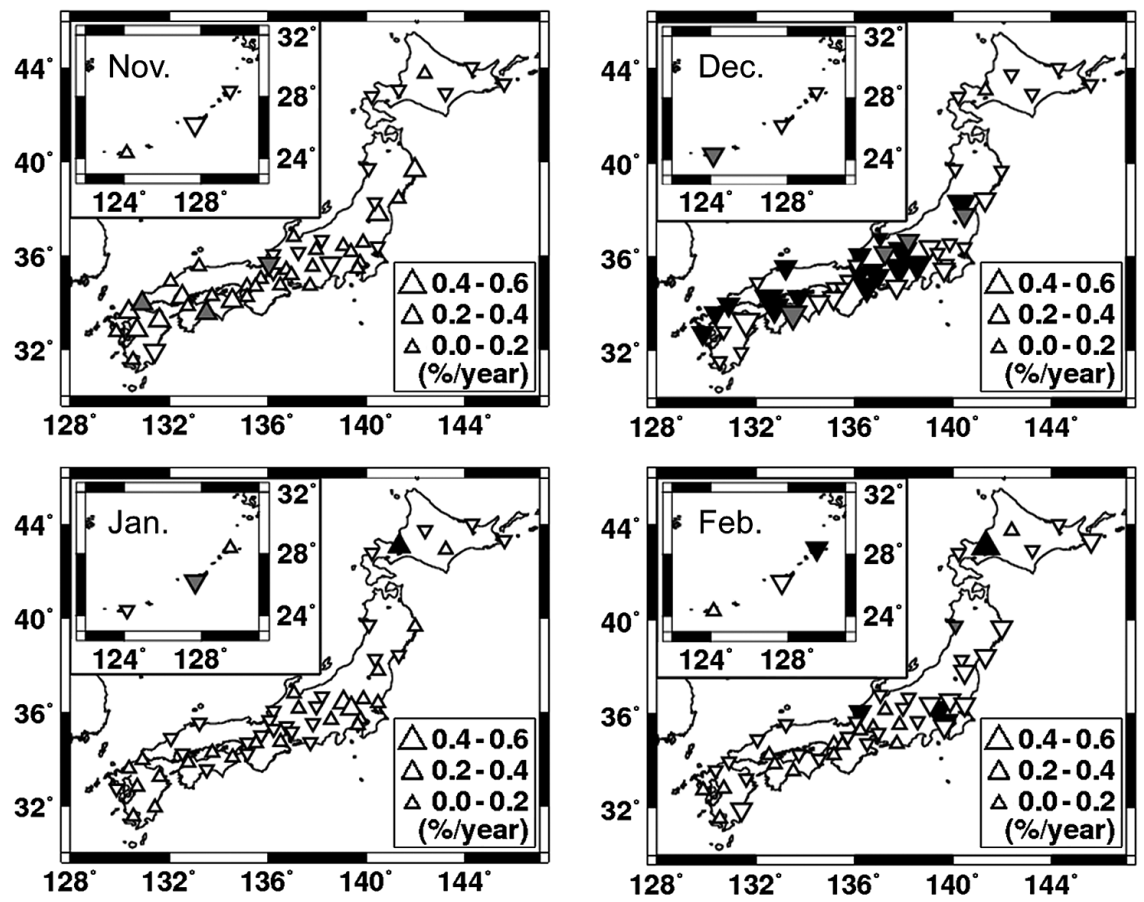

Fig. 8 Trend of PRCPTOT for each month from November through February.

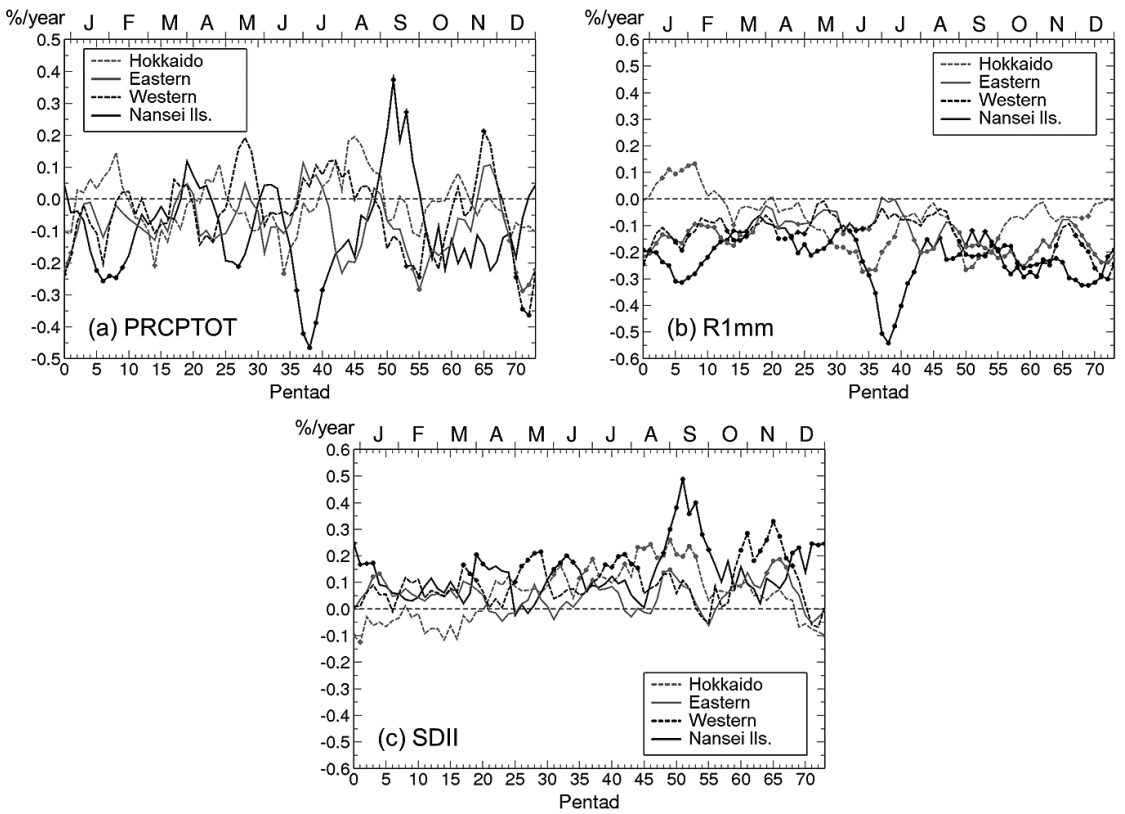

Fig. 9 Trend in six-pentad (30 day) values of (a) PRCPTOT, (b) R1mm, and (c) SDII for the four regions shown in Fig. 1.

were also common in these sub-periods, but we found some differences in intensity and/or the timing of maxima and minima. In Hokkaido, R1mm decreased from late August to September through the century, and a peak that existed during those months from 1901 to 1954 subsequently simply disappeared. Peaks in R1mm at the same time in eastern and western Japan also diminished as the century advanced. In these two regions, the peaks in precipitation and $\mathrm{R} 1 \mathrm{~mm}$ from
June to July, which correspond to the Baiu season, tended to start and end later in the year in the last half of the 20th century. In the Nansei Islands, the Baiu period was originally from late May to June, but it appears to have shortened as total precipitation and the number of days of precipitation both decreased and the subsequent dry period in July became even drier. 

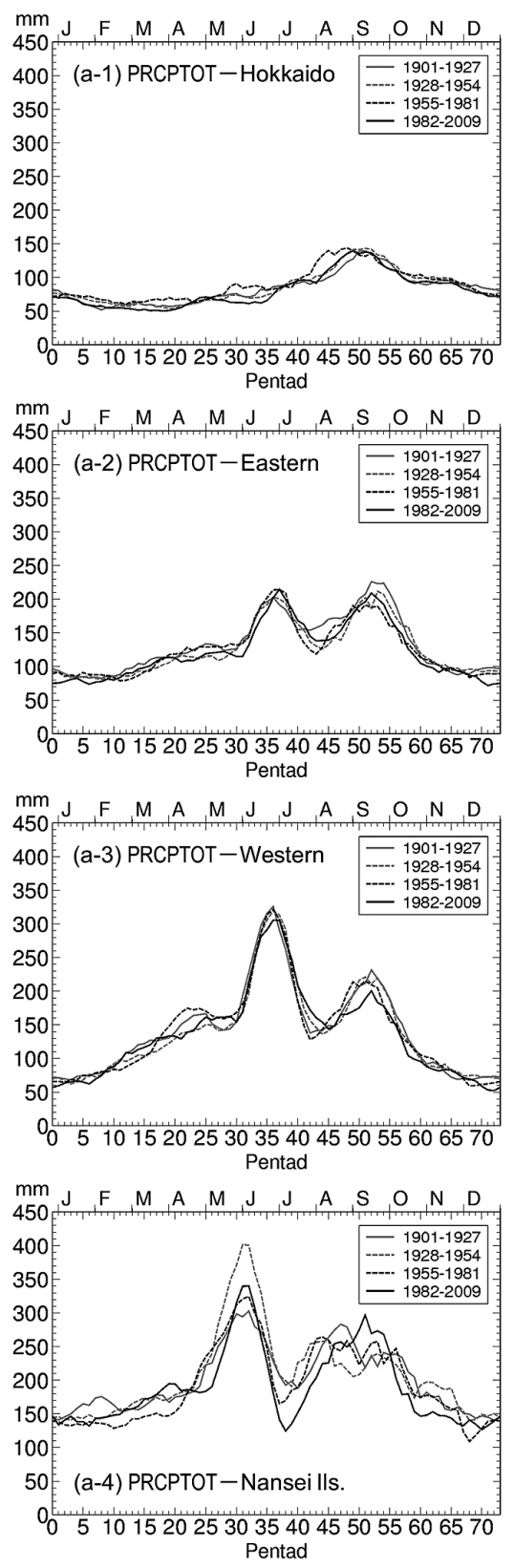
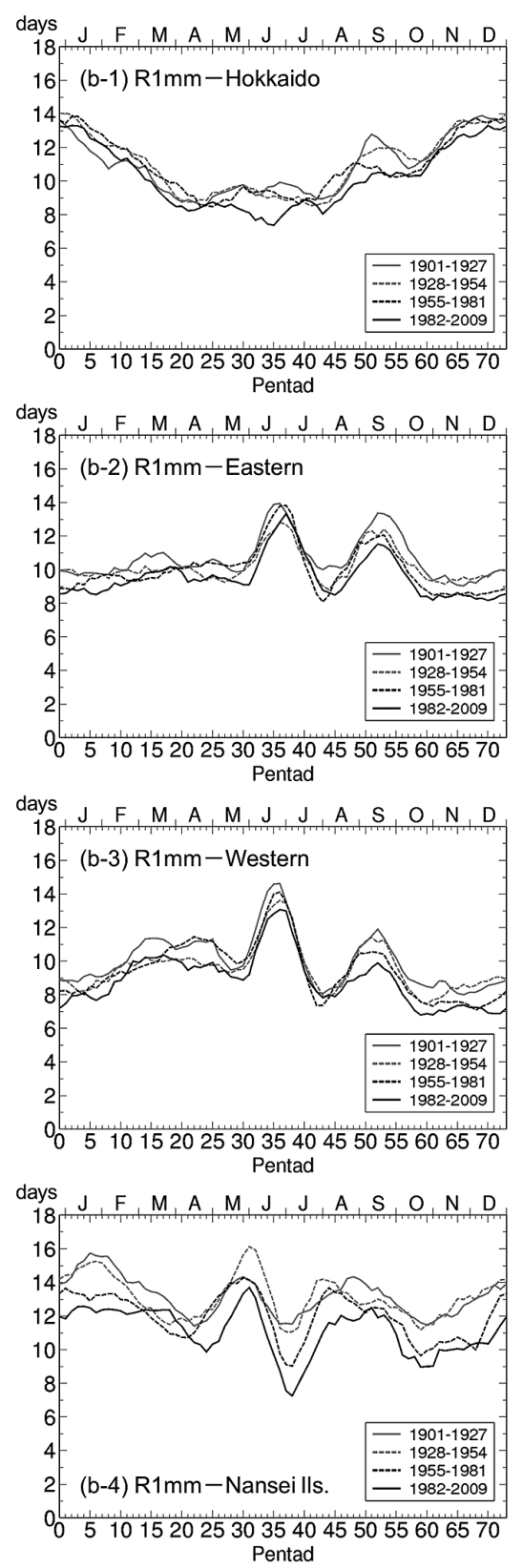

Fig. 10 Annual cycles of PRCPTOT and R1mm for four sub-periods.

\section{Discussion}

The goal of this study was to investigate detailed regional and seasonal long-term changes in precipitation in Japan by using statistically robust indices, along with CDD and CWD, which have not received detailed analysis. For Japan as a whole, our annual average trends basically agree the findings of Fujibe et al. (2006): a slight decrease in total precipitation (PRCPTOT) and a larger decrease in the number of days with precipitation (R1mm), which together caused SDII to increase. Consistent with fewer days of precipitation, CDD increased and CWD decreased. Our results are also consistent with some model projections that predicted fewer days of precipitation in Japan for the 21 st century (Kimoto et al., 2005; Kanada et al., 2010). Therefore, we confirmed the general assessment of long-term changes in annual precipitation in Japan, although the mechanism of the changes requires further research.

However, our analysis of seasonal, monthly, and 30-day running mean statistics revealed heterogeneous changes on seasonal and sub-seasonal scales with complicated regional features. Few studies have investigated regional and seasonal precipitation changes in Japan, but we compared our results with the available data. For summer, our results basically agree with those of Endo (2011), who found that precipitation decreased in early to mid-June and increased in midto late July over eastern and western Japan, which led to a prolonged Baiu period. The delayed end of the Baiu season 
in recent years is in rough agreement with some model simulations of future changes. Indeed, the seasonal march of precipitation trends (Fig. 9a) resembles the month-to-month results of a 20-km-grid global model projection (Fig. 5 of Kusunoki et al., 2011): precipitation increased in May and July, but decreased in June over eastern and western Japan. In the Nansei Islands, the downward trends that we observed in early May and early July (Fig. 9a) support the predictions of Kusunoki et al. (2011), who have simulated a sharp decrease of precipitation in May and July over the area. However, the sharp decline of PRCPTOT and R1mm from late June to early July (Fig. 9a, b) may be inconsistent with the findings of the JMA (2005), which predicted an increase of R1mm in midsummer from the Nansei Islands to western Japan.

With regard to winter, Hirano and Matsumoto (2011) observed that the "winter monsoon weather pattern", defined by a contrast in the distribution of precipitation between the Sea of Japan coast and the Pacific coast of Japan, diminished during the 20th century. The weakening of the winter monsoon over Japan has been predicted by some future climate projections (Kimoto, 2005; Hori and Ueda, 2006). The increase of CDD and the decrease of CWD on the Sea of Japan coast of Honshu (Fig. 7) appear to support a weakening of the winter monsoon. However, we found that R1mm decreased more rapidly on the Pacific coast than on the Sea of Japan coast of central Honshu, which is inconsistent with the findings of these previous studies.

Our results for regional and seasonal features of precipitation changes only partially agree with those of previous studies. One reason for the poor agreement is the scarcity of earlier data analyses and model projections for Japan, which has only recently developed models with spatial resolution capable of representing regional precipitation patterns. The reliability of the detailed features of these projections is yet to be confirmed. In fact, studies on seasonal precipitation trends have been largely confined to summer, which holds more interest from a hydrological standpoint; only a few studies deal with winter trends, and spring and autumn remain unexplored.

Another problem in our results is that statistically significant signals of seasonal and sub-seasonal changes are inadequate, even for indices considered to be robust (such as $\mathrm{R} 1 \mathrm{~mm}$ ). In this respect, our results suggest the limitations of a simple statistical approach for detecting complicated changes in precipitation, which are closely related to changes in synoptic fields. To advance our understanding of regional and seasonal precipitation trends, we need to better understand long-term variations of atmospheric circulation systems that underlie climate changes, using extensive analysis of observational fields (such as reanalysis data) and model simulations. We hope that the present paper will motivate such studies.

\section{Acknowledgments}

This article is the main part of the first author's master's thesis, which was submitted to the University of Tsukuba in 2011. The authors are grateful to staff members of the Graduate School of Life and Environmental Sciences of the university, especially those in atmospheric science. The study was made in the Cooperative Graduate School Program (of the Atmosphere-Ocean Interaction System) between the University of Tsukuba and the Meteorological Research Institute.

\section{References}

Alexander, L. V., X. Zhang, T. C. Peterson, J. Caesar, B. Gleason, A. M. G. Klein Tank, M. Haylock, D. Collins, B. Trewin, F. Rahimzadeh, A. Tagipour, K. Rupa Kumar, J. Revadekar, G. Griffiths, L. Vincent, D. B. Stephenson, J. Burn, E. Aguilar, M. Brunet, M. Taylor, M. New, P. Zhai, M. Rusticucci and J. L. Vazquez-Aguirre, 2006: Global observed changes in daily climate extremes of temperature and precipitation. J. Geophys. Res., 111, D05109, doi:10.1029.2005JD006290.

Emori, S. and S. J. Brown, 2005: Dynamic and thermodynamic changes in mean and extreme precipitation under changed climate. Geophys. Res. Lett., 32, L17706, doi:10.1029/2005GL 023272.

Endo, H., 2011: Long-term changes of seasonal progress in Baiu rainfall using 109 years (1901-2009) daily station data. SOLA, 7, 5-8.

Fujibe, F., N. Yamazaki and K. Kobayashi, 2006: Long-term change of heavy precipitation and dry weather in Japan (1901-2004). $J$. Meteor. Soc. Japan, 84, 1033-1046.

Hirano, J. and J. Matsumoto, 2011: Secular and seasonal variations of winter monsoon weather patterns in Japan since the early 20th century. Int. J. Climatol., 31, 2330-2337.

Hori, M. E. and H. Ueda, 2006: Impact of global warming on the East Asian winter monsoon, as revealed by nine coupled atmosphere-ocean GCMs. Geophys. Res. Lett., 33, L03713, doi:10.1029/2005GL024961.

IPCC, 2007: Climate Change 2007: The Physical Science Basis. Contribution of Working Group I to the Fourth Assessment Report of the IPCC, S. Solomon et al. eds., Cambridge University Press, New York, 1056 pp.

Japan Meteorological Agency, 2005: Report on Recent Climatic Change in the World. Japan Meteorological Agency, 374 pp (in Japanese; available from http://www.data.kishou.go.jp/climate/ cpdinfo/climate_change/2005/index2.html).

Kanada, S., M. Nakano and T. Kato, 2010: Projection of the future change in precipitation in the vicinity of Japan during the rainy season using a 5-km-mesh regional climate model. American Geophysical Union 2010 Fall Meeting (San Francisco, 13-17 Dec. 2010), GC41C-0926.

Kanae, S., T. Oki and A. Kashida, 2004: Changes in hourly heavy precipitation at Tokyo from 1890 to 1999. J. Meteor. Soc. Japan, 82, 241-247.

Kimoto, H., 2005: Simulated change of the east Asian circulation under the global warming scenario. Geophys. Res. Lett., 32, L16701, doi:10.1029/2005GL023383.

Kimoto, M., N. Yasutomi, C. Yokoyama and S. Emori, 2005: Projected changes in precipitation characteristics around Japan under the global warming. SOLA, 1, 85-88. 
Kusunoki, S. and R. Mizuta, 2008: Future changes in the Baiu rain band projected by a $20-\mathrm{km}$ mesh global atmospheric model: Sea surface temperature dependence. $S O L A, 4,85-88$.

Kusunoki, S., R. Mizuta and M. Matsueda, 2011: Future changes in the East Asian rain band projected by global atmospheric models with 20-km and 60-km grid size. Clim. Dyn., 37, 24812493.

WMO, 2009: Guidelines on Analysis of Extremes in a Changing Climate in Support of Informed Decisions for Adaptation. WCDMO No.72-WMO/TD-No.1500.

\title{
日本における降水の長期変動の季節特性と地域特性
}

\author{
小口哲史（筑波大学生命環境科学研究科；現所属：国際気象海洋株式会社） \\ 藤部文昭 (気象研究所予報研究部)
}

\begin{abstract}
1901〜2009 年の国内 51 地点の日降水量データを使って、降水の長期変動を調べた。降水の尺度としては、世界気象機関 (WMO) の気候委員会 $(\mathrm{CCl})$ や世界気候研究計画（WCRP）で提唱されているものの中から、降水量 (PRCPTOT)、降水 日数 $(\mathrm{R} 1 \mathrm{~mm})$ のほか、単純日降水強度 $(\mathrm{SDII})$, 最大連続無降水日 $(\mathrm{CDD})$ 、最大連続降水日（CWD）を取り上げた。こ水 らの尺度の年間統計值について、全国平均值の長期変化率（1 次トレンド）を見ると、PRCPTOT は $0.055 \% /$ 年の率で減少、 $\mathrm{R} 1 \mathrm{~mm}$ はより大きく $0.126 \% /$ 年の率で減少しており、これに伴って SDII は $0.076 \%$ / 年の増加、CDD は $0.159 \% /$ 年の増加、CWD は $0.151 \% /$ 年の減少が認められる。一方季節ごとに各尺度の変化率を見ると、さまざまな地域特性が見られ、そのパターンに 季節同士の類似性は少ない。さらに、月ごとあるいは 6 半旬平均の変化率も、月単位あるいは 1 ～ 2 ケスケールで変動して いる。こうした変動は降水の長期変化率における季節的特性の一端を捉えていると考えられ、東〜西日本で梅雨期間が遅れる 傾向など将来気候予測実験で得られた特徵と共通する部分もある。しかし、今回の結果にはデータ数の制約による不確実性が 影響している可能性もあり、降水の長期変化の地域性や季節性をより正確に捉えていくためには、それをもたらす循環場に対 する研究を進めることが必要であると考えられる。
\end{abstract}

